\title{
Analisis kepuasan pernikahan pada pasangan suami istri yang bekerja
}

\author{
Monika Veronika ${ }^{1}$, Afdal Afdal $^{1}$ \\ Universitas Negeri Padang, Indonesia
}

\begin{tabular}{l} 
Article Info \\
\hline Article history: \\
Received Jun $18^{\text {th }}, 2021$ \\
Revised Jul $27^{\text {th }}, 2021$ \\
Accepted Aug $22^{\text {th }}, 2021$ \\
\hline
\end{tabular}

\section{Keyword:}

Kepuasan

Pernikahan

\begin{abstract}
Kepuasan pernikahan merupakan penilaian subjektif dari masing-masing individu terhadap mutu ataupun kualitas secara keseluruhan dalam pernikahannya. Kepuasan pernikahan akan berbeda pada pasangan yang sama-sama bekerja dengan pasangan yang hanya suami atau istri saja yang bekerja. Penelitian ini menggunakan jenis penelitian kuantitatif metode deskriptif. Sampel dalam penelitian ini sebanyak 30 orang (15 pasangan suami istri). Instrumen dalam penelitian ini adalah instrumen kepuasan pernikahan dan tergolong ke dalam typical performance test. Data penelitian dianalisis dan dideskripsikan dengan menggunakan rumus persentase. Hasil penelitian menunjukkan kepuasan pernikahan pada pasangan suami istri baik pada suami maupun istri sama-sama berada pada kategori tinggi pada seluruh aspek. Berdasarkan hasil penelitian konselor diharapkan dapat memberikan pelayanan konseling sebagai upaya untuk meningkatkan kepuasan pernikahan bagi pasangan suami istri yang bekerja melalui layanan informasi, layanan penguasaan konten, layanan konseling perorangan, dan layanan mediasi.
\end{abstract}

\section{Corresponding Author:}

Afdal, A.,

Universitas Negeri Padang, Indonesia

Email: afdal@konselor.org

\section{Pendahuluan}

Pernikahan merupakan satu ikatan yang berkaitan erat dengan emosional dan fisik seseorang, yang dapat membuat individu merasakan kebahagiaan dan kepuasan (Olson, DeFrain, \& Skogrand, 2010). Tujuan suatu pernikahan ialah untuk dapat merasakan kebahagiaan, cinta dan kasih sayang, keturunan, serta kepuasan (Patmonodewo et al., 2001).

Kepuasan serta kebahagiaan dalam pernikahan menurut Hurlock (1991), merupakan acuan dari keberhasilan suami dan istri dalam menjalani kehidupan sebagai pasangan serta dalam memecahkan suatu permasalahan. Pada kenyataannya, tidak semua pasangan dapat mencapai kepuasan dalam pernikahan (Putra \& Afdal, 2020). Kepuasan pernikahan juga merujuk pada perasaan positif yang dapat dirasakan oleh pasangan suami istri dalam suatu pernikahan yang meliputi kebahagiaan, kenikmatan, kesukaan (Lestari, 2016) serta berbagai hal menyenangkan dalam pernikahan, hal tersebut tentunya menjadi suatu penilaian yang berbedabeda yang dimiliki oleh pasangan suami istri (Olson et al., 2010).

Kepuasan pernikahan merupakan penilaian subjektif dari masing-masing individu terhadap mutu ataupun kualitas secara keseluruhan dalam pernikahannya serta merupakan hal utama atau puncak dari kebahagiaan dalam pernikahan yang dirasakan oleh pasangan suami istri. Penilaian tersebut berhubungan dengan harapan yang dibangun dalam pernikahan, rasa bahagia yang dirasakan selama menjalani sebuah ikatan pernikahan 
apa yang dibutuhkan dalam pernikahan, serta terpenuhi atau tidaknya keinginan dan harapan dari pasangan suami istri dalam sebuah pernikahan (Kisiyanto, 2018; Paputungan, 2011).

Hasil penelitian Sorokowski, Randall, Groyecka, \& Frackowiak (2017) mengenai kepuasan pernikahan di seluruh dunia dengan menggunakan Marriage and Relationship Quistionnaire (MRQ) yang dikembangkan oleh Russell and Wells pada tahun 1993, hasil penelitian menyebutkan bahwa kepuasan pernikahan tertinggi dengan skala 0,94 (Hongkong, Romania dan Canada) sementara itu kepuasan pernikahan terendah dengan skala 0,74 (Kazakhstan). Sedangkan, Indonesia berada di posisi 20 dari 33 negara dengan skala 0,91. Dapat disimpulkan bahwa Indonesia berada pada kategori normal dengan skala yang tidak terlalu tinggi ataupun terlalu rendah.

Sepuluh aspek yang menjadi acuan kepuasaan atau kebahagiaan dalam pernikahan menurut David H. Olson, yakni: komunikasi, kecocokan kepribadian, kedekatan, fleksibilitas, kegiatan mengisi waktu luang, pemecahan masalah, keyakinan beragama, relasi seksual, keluarga dan teman, serta pengelolaan keuangan (Lestari, 2016). Adapun berbagai komponen yang dapat mempengaruhi kepuasan pernikahan, yakni komunikasi yang baik, menghabiskan waktu luang bersama, keyakinan beragama, kekompakan dalam mengatasi permasalahan, manajemen keuangan, orientasi seksual, hubungan individu dengan keluarga dan teman, pola asuh anak, kepribadian yang sama, serta kesetaraan peran (Fowers \& Olson, 1993).

Aspek kesamaan peran menjadi perhatian lebih dalam penelitian ini, kesamaan peran merupakan aspek yang mengukur tentang perasaan maupun sikap individu mengenai peran yang dijalankan pasangan suami istri dalam kehidupan pernikahan. Kesamaan peran tidak berarti suami dan istri harus melakukan pekerjaan yang sama, tetapi tetap pada peran masing-masing sebagai suami dan istri. Suami dengan tugasnya mencari nafkah, istri yang mengurusi segala keperluan rumah tangga. Istri dapat mengembangkan karir diluar rumah, namun harus tetap memenuhi tanggung jawab dan perannya sebagai istri dan ibu yang merupakan peran utamanya (Kusumowardhani, 2012; Paputungan, 2011).

Pasangan suami istri yang memilih untuk sama-sama bekerja memiliki dampak positif dan negatif dalam kehidupan pernikahan. Dampak positifnya antara lain adalah adanya kesiapan jika terjadi sesuatu pada pasangan seperti PHK, bercerai, meninggal, dan sebagainya, serta meningkatkan pengertian istri terhadap suami untuk membantu memenuhi kebutuhan rumah tangga (Meliani, Sunarti, \& Krisnatuti, 2014). Selanjutnya, dampak negatif jika suami istri bekerja adalah istri yang bekerja sekaligus mengurus pekerjaan rumah tangga dapat meningkatkan ketegangan dan konflik dalam pernikahan, banyak waktu yang dihabiskan di luar rumah, sehingga urusan rumah tangga terabaikan (Desmayanti, 2009). Namun, tidak semua pasangan yang sama-sama bekerja memiliki komitmen dan kepuasan pernikahan yang rendah serta berakhir pada perceraian, masih banyak pasangan suami istri bekerja yang memperoleh kepuasan dalam pernikahannya dan mampu mempertahankan pernikahannya (Kusumowardhani, 2012; Latifatunnikmah \& Lestari, 2020; Muhid, Nurmamita, \& Hanim, 2019).

\section{Metode}

Penelitian ini merupakan penelitian dengan pendekatan kuantitatif serta metode yang digunakan ialah metode deskriptif. Dalam penelitian ini, yang akan dideskripsikan ialah kepuasan pernikahan pada pasangan suami istri yang bekerja. Penarikan sampel dalam penelitian memakai teknik purposive sampling dikarenakan tidak semua sampel memiliki kriteria yang sesuai dengan fenomena yang akan diteliti yaitu pasangan suami istri yang bekerja. Jumlah sampel dalam penelitian ini sebanyak 30 orang (15 pasangan suami istri). Instrumen yang digunakan dalam penelitian ini ialah instrumen kepuasan pernikahan yang mengacu pada teori Fowers dan Olson tahun 1993 berjumlah 40 item, dan tergolong ke dalam typical performance test, serta mengukur aspek komunikasi, aktivitas bersama, orientasi keagamaan, pemecahan masalah, manajemen keuangan, orientasi seksual, keluarga dan teman, anak-anak dan pengasuhan, masalah kepribadian, dan kesamaan peran. Selanjutnya, data penelitian akan dianalisis dan dideskripsikan dengan menggunakan rumus persentase.

\section{Hasil dan Pembahasan}

Hasil pengumpulan dan pengolahan data melalui instrumen kepuasan pernikahan dari keseluruhan sampel yang berjumlah 30 orang yang terdiri dari pasangan suami istri, dapat dilihat pada tabel 1:

Tabel 1 memperlihatkan bahwa terdapat 30 orang subjek penelitian yang terdiri dari 15 pasangan suami istri, tingkat kepuasan pernikahan pada laki-laki (suami), sebagian besar memiliki kepuasan pernikahan yang sangat tinggi yakni sebanyak delapan orang dengan persentase sebesar $26,67 \%$ dan berada pada kategori sedang sebanyak satu orang dengan persentase $3,33 \%$. 
Tabel $1<$ Distribusi Frekuensi dan Persentasi Kepuasan Pernikahan>

\begin{tabular}{lcccc}
\hline Jenis Kelamin & Kategori & Skor & $\mathbf{F}$ & $\mathbf{0}$ \\
& Sangat Tinggi (ST) & $\geq 136$ & 8 & 26,67 \\
Laki-laki & Tinggi (T) & $112-135$ & 0 & 0,00 \\
(Suami) & Sedang (S) & $88-111$ & 2 & 6,67 \\
& Rendah (R) & $64-87$ & 4 & 13,33 \\
& Sangat Rendah (SR) & $\leq 63$ & 1 & 3,33 \\
& Jumlah & & $\mathbf{1 5}$ & $\mathbf{5 0 , 0 0}$ \\
Perempuan & Sangat Tinggi (ST) & $\geq 136$ & 8 & 26,67 \\
(Istri) & Tinggi (T) & $112-135$ & 0 & 0,00 \\
& Sedang (S) & $88-111$ & 1 & 3,33 \\
& Rendah (R) & $64-87$ & 5 & 16,67 \\
& Sangat Rendah (SR) & $\leq 63$ & 1 & 3,33 \\
\hline
\end{tabular}

Selanjutnya, tingkat kepuasan pernikahan perempuan (istri) sebagian besar berada pada kategori sangat tinggi yaitu sebanyak delapan orang dengan persentase $26,67 \%$ dan berada pada kategori sangat rendah dengan persentase sebesar 3,33\%. Data kepuasan pernikahan berdasarkan aspek diuraikan lebih rinci pada tabel 2.

Tabel $2<$ Kategorisasi Kepuasan Pernikahan Berdasarkan Aspek>

\begin{tabular}{|c|c|c|c|c|c|c|c|c|c|}
\hline No & Aspek & Jenis Kelamin & $\begin{array}{c}\text { Jumlah } \\
\text { Item }\end{array}$ & Max & Min & Mean & SD & $\%$ & Kategori \\
\hline \multirow{2}{*}{1} & & Laki-laki & \multirow{2}{*}{ Fom } & 16 & 5 & 11 & 5 & 37,11 & $\mathrm{~T}$ \\
\hline & Komunikas1 & Perempuan & & 16 & 5 & 11 & 5 & 35,11 & $\mathrm{~T}$ \\
\hline \multirow{2}{*}{2} & Aktivitas & Laki-laki & \multirow{2}{*}{4} & 16 & 5 & 11 & 4 & 37,78 & $\mathrm{~T}$ \\
\hline & Bersama & Perempuan & & 16 & 5 & 11 & 4 & 35,78 & $\mathrm{~T}$ \\
\hline \multirow{2}{*}{3} & Orientasi & Laki-laki & \multirow[b]{2}{*}{4} & 15 & 5 & 11 & 3 & 37,33 & $\mathrm{~T}$ \\
\hline & Keagamaan & Perempuan & & 16 & 5 & 11 & 4 & 36,67 & $\mathrm{~T}$ \\
\hline \multirow{2}{*}{4} & Pemecahan & Laki-laki & \multirow{2}{*}{4} & 16 & 4 & 11 & 4 & 38,00 & $\mathrm{~T}$ \\
\hline & Masalah & Perempuan & & 16 & 5 & 11 & 5 & 37,33 & $\mathrm{~T}$ \\
\hline \multirow{2}{*}{5} & Manajemen & Laki-laki & \multirow[b]{2}{*}{4} & 16 & 5 & 11 & 4 & 37,33 & $\mathrm{~T}$ \\
\hline & Keuangan & Perempuan & & 16 & 4 & 11 & 4 & 37,56 & $\mathrm{~T}$ \\
\hline \multirow{2}{*}{6} & Hubungan & Laki-laki & \multirow{2}{*}{4} & 16 & 5 & 11 & 4 & 38,00 & ST \\
\hline & Seksual & Perempuan & & 16 & 6 & 12 & 4 & 40,22 & ST \\
\hline \multirow{2}{*}{7} & Keluarga & Laki-laki & \multirow[b]{2}{*}{4} & 16 & 5 & 11 & 4 & 37,78 & $\mathrm{~T}$ \\
\hline & dan Teman & Perempuan & & 16 & 5 & 12 & 4 & 38,44 & $\mathrm{~T}$ \\
\hline \multirow{2}{*}{8} & Anak dan & Laki-laki & \multirow[b]{2}{*}{4} & 16 & 5 & 12 & 4 & 39,11 & ST \\
\hline & Pengasuhan & Perempuan & & 16 & 5 & 11 & 5 & 38,22 & ST \\
\hline \multirow{2}{*}{9} & Masalah & Laki-laki & \multirow{2}{*}{4} & 16 & 5 & 11 & 4 & 37,56 & ST \\
\hline & Kepribadian & Perempuan & & 16 & 5 & 12 & 4 & 39,33 & ST \\
\hline \multirow{2}{*}{10} & Kesamaan & Laki-laki & & 16 & 5 & 13 & 3 & 42,44 & ST \\
\hline & Peran & Perempuan & & 16 & 8 & 13 & 2 & 43,56 & ST \\
\hline
\end{tabular}

\section{Keterangan:}

$\begin{array}{ll}\text { Max } & =\text { Skor Maksimal } \\ \text { Min } & =\text { Skor Minimal } \\ \text { Mean } & =\text { Rata-rata } \\ \text { SD } & =\text { Standar Deviasi }\end{array}$

$$
\begin{array}{ll}
\% & =\text { Persentase } \\
\mathrm{ST} & =\text { Sangat Tinggi } \\
\mathrm{T} & =\text { Tinggi }
\end{array}
$$

Tabel 2 menunjukkan kepuasan pernikahan pasangan suami istri berdasarkan aspek. Kepuasan pernikahan laki-laki (suami) persentase tertinggi yaitu $42,44 \%$ berada pada aspek kesamaan peran, sedangkan persentase terendah yaitu $37,11 \%$ pada aspek komunikasi. Selanjutnya, kepuasan pernikahan pada perempuan (istri) persentase tertinggi $43,56 \%$ yaitu pada aspek kesamaan peran, dan persentase terendah $35,11 \%$ pada aspek komunikasi.

Berdasarkan hasil penelitian dapat disimpulkan bahwa kepuasan pernikahan pada pasangan suami istri yang bekerja secara keseluruhan berada pada kategori tinggi. Namun, kepuasan pernikahan tidak bersifat statis, ia berubah sesuai kondisi dan waktu. Duvall \& Miller (1985), mengemukakan bahwa tingkat kepuasan 
pernikahan biasanya akan tinggi di masa-masa awal pernikahan, kemudian akan menurun setelah kehadiran anak dan kemudian meningkat kembali setelah anak mandiri. Kemudian Lavner, Karney, \& Bradbury (2014), mengatakan bahwa pasangan suami istri memulai pernikahannya dengan merasakan kepuasan, akan tetapi kepuasan ini perlahan menurun setelah beberapa tahun dan akan kembali meningkat setelah beberapa tahun bersama sebagai pasangan dan mencapai tingkat kepuasan yang sama seperti di awal pernikahan.

Kepuasan pernikahan merupakan bagian penting dalam sebuah pernikahan, baik bagi suami maupun istri, kepuasan pernikahan sangat berpengaruh terhadap kebahagiaan individu. Kepuasan pernikahan diciptakan oleh pasangan itu sendiri, perlu adanya kesadaran mengenai rumah tangga untuk mencapai kepuasan pernikahan (Rosana \& Ediati, 2018). Kepuasan pernikahan dan kemampuan mempertahankan keharmonisan dalam pernikahan merupakan salah satu indikator suatu keberhasilan dalam kehidupan pernikahan yang dijalani oleh pasangan menikah atau suami istri (Meliani et al., 2014).

Suami maupun istri tentu mengharapkan kehidupan pernikahan yang bahagia dan puas (Islamy \& Ningsih, 2019). Pada kenyataannya, tidak semua pasangan dapat mencapai kepuasan dalam pernikahan (Putra \& Afdal, 2020). Meskipun tingkat kepuasan pernikahan pasangan suami istri dalam penelitian ini ratarata berada pada kategori sangat tinggi, namun tetap saja dibutuhkan usaha agar kepuasan pernikahan tidak berkurang seiring berjalannya waktu. Hal tersebut dipertegas oleh hasil penelitian Herawati \& Widiantoro (2019), yang mengemukakan bahwa kepuasan pernikahan pada pasangan suami istri umumnya meningkat saat pernikahan, akan tetapi dapat menurun pada saat pernikahan memasuki usia 10 tahun.

Berdasarkan pendapat tersebut maka dapat disimpulkan bahwa pasangan suami istri yang bekerja mempunyai kepuasan pernikahan yang baik, namun sewaktu-waktu bisa saja berubah, dan masih terdapat pasangan yang mempunyai kepuasan pernikahan yang rendah, terutama pada aspek komunikasi yang memiliki persentase terendah dari keseluruhan aspek. Oleh karena itu, bimbingan dan konseling sangat dibutuhkan dalam hal ini untuk membantu pasangan dalam mereduksi kemungkinan kepuasan pernikahan akan menurun. Sebagaimana tujuan dari konseling keluarga yaitu membantu pengentasan masalah yang khusus menangani berbagai permasalahan dalam rumah tangga (Ismaya, 2015) termasuk memperoleh kepuasan dalam pernikahan, dengan memberikan bantuan melalui sistem kekeluargaan (pembenahan komunikasi keluarga) agar potensi yang dimiliki dapat berkembang secara optimal, sehingga dapat mengatasi berbagai masalah dalam keluarga (Willis, 2013).

\section{Kesimpulan}

Kepuasan pernikahan bukan hal baru dari permasalahan pernikahan, namun upaya intensif untuk meningkatkan kepuasan pernikahan sepertinya tidak banyak dilakukan di Indonesia, kondisi ini terlihat dari kurangnya perhatian terhadap kasus perceraian yang disebabkan oleh kurangnya kepuasan pernikahan. Semoga kedepannya peningkatan, pengembangan dan optimalisasi layanan bimbingan dan konseling untuk meningkatkan kepuasan pernikahan dapat terselenggara, perlunya layanan bimbingan dan konseling untuk menurunkan level stres yang dialami oleh pasangan suami istri yang bekerja. Konselor diharapkan dapat memberikan pelayanan konseling sebagai upaya untuk meningkatkan kepuasan pernikahan bagi pasangan suami istri yang bekerja. Dalam penelitian ini yang menjadi perhatian ialah kepuasan pernikahan agar pasangan suami istri dapat merasakan kebahagiaan dan keharmonisan dalam kehidupan pernikahan. Dilihat dari nilai rata-rata laki-laki maupun perempuan berada pada kategori tinggi, namun jika dilihat dari aspekaspek kepuasan pernikahan yang diteliti yaitu aspek komunikasi memiliki nilai rata-rata yang rendah. Oleh karena itu, konselor dapat memberikan layanan bimbingan dan konseling yang berkaitan dengan membangun komunikasi yang baik dengan pasangan dan menciptakan kenyamanan yang dirasakan oleh pasangan dalam membagi dan menerima informasi emosional serta kognitif, melalui layanan informasi, layanan penguasaan konten, layanan konseling perorangan, dan layanan mediasi.

\section{Referensi}

Desmayanti, S. (2009). Hubungan antara Resolusi Konflik dan Kepuasan Pernikahan pada Pasangan Suami Istri Bekerja pada Masa Awal Pernikahan. Universitas Indonesia.

Duvall, E. M., \& Miller, B. C. (1985). Marriage and Family Development (Sixth Edition). New York: Harper \& Row.

Fowers, B., \& Olson, D. (1993). ENRICH Marital Satisfaction Scale: A Brief Research and Clinical Tool. Journal of Family Psychology, 7(2).

Herawati, I., \& Widiantoro, D. (2019). Kebersyukuran dan Kemaafaan terhadap Kepuasan Pernikahan. AlHikmah: Jurnal Agama Dan Ilmu Pengetahuan, 16(2), 108-119. 
Hurlock, E. (1991). Psikologi Perkembangan: Suatu Pendekatan Sepanjang Rentang Kehidupan. Jakarta: Erlangga.

Islamy, T. P., \& Ningsih, Y. T. (2019). Hubungan antara Perilaku Asertif dengan Kepuasan Pernikahan pada Istri Polisi. Jurnal Riset Psikologi, $9(1)$.

Ismaya, B. (2015). Bimbingan dan Konseling: Studi, Karir, dan Keluarga. Bandung: Refika Aditama.

Kisiyanto, S. (2018). Relasi Finansial , Resolusi Konflik, dan Kepuasan Pernikahan pada Pernikahan Sepuluh Tahun ke Bawah. Psychopreneur Journal, 2(2), 92-102.

Kusumowardhani, R. P. . A. (2012). Gambaran Kepuasan Perkawinan pada Istri Bekerja. Proyeksi, 6(1), 1-15.

Latifatunnikmah, \& Lestari, S. (2020). Komitmen Pernikahan pada Pasangan Suami Istri yang Bekerja. Jurnal Humanitas, 14(2), 103-119.

Lavner, J. A., Karney, B. R., \& Bradbury, T. N. (2014). Relationship Problems Over The Early Years of Marriage: Stability or Change? Journal of Family Psychology, 28(6), 979.

Lestari, S. (2016). Psikologi Keluarga (Penanaman Nilai dan Penanganan Konflik dalam Keluarga). Jakarta: Prenadamedia Group.

Meliani, F., Sunarti, E., \& Krisnatuti, D. (2014). Faktor Demografi Konflik Kerja-Keluarga dan Kepuasan Perkawinan Istri Bekerja. Jurnal Ilmu Keluarga Dan Konsumen, 7(3).

Muhid, A., Nurmamita, P. E., \& Hanim, L. M. (2019). Resolusi Konflik dan Kepuasan Pernikahan : Analisis Perbandingan Berdasarkan Aspek Demografi, 5(1), 49-61.

Olson, D., DeFrain, J., \& Skogrand, L. (2010). Marriage and Families: Intimacy, Diversity, and Strengths (7th Edition). New York: The McGraw Hill Companies.

Paputungan, F. (2011). Kepuasan Pernikahan Suami yang Memiliki Istri Berkarir. Jurnal Psikologi, 9(10), 1-19.

Patmonodewo, S., Atmodiwirjo, E. T., Marat, S., Munandar, U. S. ., Gunarsa, S. D., Soewondo, S., \& Achir, Y. C. A. (2001). Bunga Rampai Psikologi Perkembangan Pribadi dari Bayi Sampai Lanjut Usia. Jakarta: UI Press.

Putra, B. N., \& Afdal. (2020). Marital Satisfaction: An Analysis of Long Distance Marriage Couples. International Journal of Research in Counseling and Education, 4(1), 64-69.

Rosana, E., \& Ediati, A. (2018). Hubungan antara Sikap terhadap Pernikahan dengan Kepuasan Pernikahan pada Istri. Jurnal Empati, 7(April), 220-227.

Sorokowski, P., Randall, A. K., Groyecka, A., \& Frackowiak, T. (2017). Marital Satisfaction, Sex, Age, Marriage Duration, Religion, Number of Children, Economic Status, Education, and Collectivistic Values: Data from 33 Countries, 8(July), 1-7. https://doi.org/10.3389/fpsyg.2017.01199

Willis, S. S. (2013). Konseling Keluarga (Family Counseling). Bandung: Alfabeta. 